\title{
PENGELOLAAN SARANA DAN PRASARANA DI PAUD
}

\author{
Baiq Rohiyatun ${ }^{1}$, Lu'luin Najwa ${ }^{2}$ \\ Universitas Pendidikan Mandalika \\ bq.rohiyatun@gmail.com
}

\begin{abstract}
Abstrak: Salah satu upaya dalam meningkatkan mutu Pendidikan Anak Usia Dini adalah dengan cara terpenuhinya sarana dan prasarana yang ada di lembaga Pendidikan Anak Usia Dini yang memadai, berkualitas, sesuai dengan perkembangan Anak Usia Dini, dan sarana dan prasarana yang siap pakai. Oleh karena itu untuk meningkatkan kualitas Pendidikan Anak Usia Dini diperlukan suatu manajemen sarana dan prasarana yang baik. Sarana dan prasarana pendidikan juga menjadi salah satu tolak ukur dari mutu sekolah. Tetapi fakta di lapangan banyak ditemukan sarana dan prasarana yang tidak dioptimalkan dan dikelola dengan baik. Ada beberapa kagiatan yang dilakukan dalam pengelolaan sarana dan prasarana yaitu: Perencanaan sarana dan prasarana, Pengadaan sarana dan prasarana, Inventarisasi sarana dan prasarana, Pemanfaatan sarana dan prasarana, Pemeliharaan sarana dan Prasarana dan Penghapusan sarana dan prasarana.
\end{abstract}

\section{Kata Kunci: Pengelolaan, sarana prasarana, PAUD}

\section{Pendahuluan}

Sarana dan prasarana pendidikan menjadi salah satu tolak ukur dari mutu sekolah. Tetapi fakta dilapangan banyak ditemukan sarana dan prasarana yang tidak dioptimalkan dan dikelola dengan baik untuk itu diperlukan pemahaman dan pengaplikasian manajemen sarana dan prasarana pendidikan persekolahan berbasis sekolah. Bagi pengambil kebijakan di sekolah pemahaman tentang sarana dan prasarana akan membantu memperluas wawasan tentang bagaimana ia dapat berperan dalam merencanakan, menggunakan dan mengevaluasi sarana dan prasarana yang ada sehingga dapat dimanfaatkan dengan optimal guna mencapai tujuan pendidikan.

Peraturan Pemerintah No. 19 Tahun 2005 tentang Standar nasional Pendidikan, pasal 1 ayat (8) mengemukakan standar sarana dan prasarana adalah Standar Nasional Pendidikan yang berkaitan kriteria minimal tentang ruang belajar, tempat olah raga, tempat beribadah, perpustakaan, laboratorium, bengkel kerja, tempat bermain, tempat berekreasi dan berkreasi, serta sumber belajar lain yang diperlukan untuk menunjang proses pembelajaran termasuk penggunaan teknologi informasi dan komunikasi. pada Bab VII Pasal 42 dengan tegas disebutkan bahwa; (1) Setiap satuan pendidikan wajib memiliki sarana yang meliputi perabot, peralatan pendidikan, media pendidikan, buku dan sumber belajar lainnya, bahan habis pakai, serta perlengkapan lain yang diperlukan untuk menunjang proses pembelajaran yang teratur dan berkelanjutan.

Menurut Tim Pakar Manajemen Pendidikan (2003:86) "pengelolaan sarana dan 
prasarana pendidikan dapat didefinisikan sebagai proses kerjasama pendayagunaan semua sarana dan prasarana pendidikan secara efektif dan efisien". Wahyuingrum (2000:5), berpendapat bahwa sarana pendidikan adalah "segala fasilitas yang diperlukakan dalam proses pembelajaran, yang dapat meliputi barang bergerak maupun barang yang tidak bergerak agar tujuan pendidikan tercapai". Menurut Ibrahim Bafadal (2003:2) bahwa "prasarana pendidikan adalah semua perangkat kelengkapan dasar yang tidak langsung menunjang pelaksanaan proses pendidikan di sekolah. Sedangkan Menurut Riduwan (2009), prasarana pendidikan dapat diartikan sebagai perangkat penunjang utama suatu proses atau usaha pendidikan agar tujuan pendidikan tercapai. Dari pendapat di atas diambil kesimpulan bahwa prasarana pendidikan adalah perangkat yang menunjang keberlangsungan proses pendidikan agar tujuan pendidikan tercapai.

\section{Tinjauan Pustaka}

Berdasarkan kamus Besar Bahasa Indonesia (1996:123), "sarana adalah segala sesuatu yang dapat digunakan sebagai alat dalam mencapai suatu maksud atau tujuan" Menurut E. Mulyasa, sarana pendidikan adalah peralatan dan perlengkapan yang secara langsung dipergunakan dan menunjang proses pendidikan, khususnya proses belajar, mengajar, seperti gedung, ruang kelas, meja kursi, serta alat-alat media pengajaran". Sedangkan pengertian prasarana berdasarkan kamus besar bahasa indonesia (1996:109) yaitu" segalah sesuatu yang merupakan penunjang utama terselenggaranya suatu proses".

Berdasarkan beberapa pendapat di atas dapat disimpulkan, bahwa sarana pendidikan adalah segala fasilitas bisa berupa peralatan, bahan dan perabot yang langsung di pergunakan dalam proses belajar di sekolah. Sedangkan prasarana pendidikan merupakan segalah sesuatu yang secara tidak langsung menunjang proses pendidikan. Menurut Oteng (2001 :33) setiap sekolah memiliki prinsip-prinsip dan tata tertib mengenai penggunaan dan pemeliharaan sarana dan prasarana sekolah, hal itu bertujuan untuk mempermudah administrator dalam mengawasi dan mengatur sarana dan prasarana di sekolah tersebut.

Sarana dan prasarana pendidikan pada dasarnya dapat dikelompokan dalam empat kelompok, yaitu tanah, bangunan, perlengkapan, dan perabot sekolah (side, building, equipment, and furniture). Agar semua fasilitas tersebut tersebut memberikan kontribusi yang berarti pada jalannya proses pendidikan, hendaknya dikelolah dengan baik. Pengelolaan yang dimaksud meliputi: (1) perencanaan, (2) pengadaan, (3) penggunaan, (4) pemeliharan dan (5) penghapusan.

Sarana dan prasaran pendidikan, khususnya lahan, bangunan dan pelengkapan sekolah menggambarkan program pendidikan atau kurikulum sekolah itu. Karena bangunan dan perlengkapan sekolah tersebut diadakan dengan berlandaskan pada kurikulum atau program pendidikan yang berlaku, sehingga dengan adanya kesesuaian itu memungkinkan fasilitas yang ada benar- benar menunjang jalanya proses ppendidikan. Pengelolaan bahan bangunan, dan perlengkapan sekolah merupakan tanggung jawab kepalah sekolah.

\section{Hasil Penelitian dan Pembahasan}

Pengelolaan Sarana dan Prasarana di PAUD dimulai dari perencanaan, pengadaan, inventarisasi, pemanfaatan dan pemeliharaan. 
1. Perencanaan Perlengkapan PAUD

Adapun prosedur perencanaan perlengkapan pada PAUD dilakukan oleh pengelola bersama guru- guru, tugas guru melaporkan kepada pengelola tentang sarana pembelajaran yang dibutuhkan kemudian pengelola mempertimbangkan dengan keuangan sekolah, melalui kebutuhan sarana pembelajaran yang dilaporkan maka pihak sekolah melakukan perencanaan tentang sarana yang akan diadakan tentunya disesuaikan dengan keuangan sekolah.Perencanaan ini dilakukan secara terus menerus selama kegiatan sekolah berlangsung, perencanaan ini biasanya dilakukan setiap akhir tahun ajaran. dalam perencanaan ini harus ada kerjasama yang baik antara kepala sekolah, guru, tata usaha (TU) sehingga mudah dalam merencanakan apa yang hendak menjadi bahan atau perlengkapan yang sekolah butuhkan.

Perencanaan sarana prasarana ini tidak boleh dekat waktunya dengan penggunaan alat tersebut, karena prosedur pengajuan anggaran itu tidak dapat dilakukan sewaktu-waktu oleh karena itu perencanaan harus disesuaikan dengan waktu yang telah ditentukan. Kompri (2015:19) perencanaan yang terpenting adalah pembuatan keputusan yang merupakan proses mempersiapkan segala sesuatu yang diperlukan dalam pembuatan perencanaan untuk perubahan menuju pada tujuan yang telah ditetapkan. Dalam setiap perencanaan yang dilakukan harus ada kesepakatan dan kerjasama antar kepala PAUD dan guru, sehingga perencanaan yang dilakukan ini bisa berjalan dengan lancar, perencanaan ini merupakan kegiatan yang dilakukan diakhir tahun ajaran, untuk mempersiapkan apa-apa saja yang akan diperlukan, baik memperbaiki segala meja kursi dan lain-lainnya.

2. Pengadaan Perlengkapan PAUD

Melalui hasil perencanaan yang matang pengadaan perlengkapan ditetapkan oleh pengelola dan guru-guru. Setelah ada daftar kebutuhan perlengkapan pengelola belanja sesuai kebutuhan yang disepakati bersama. Pengadaan sarana prasarana yang dilakukan disekolah adalah dengan cara membeli menyiapkan segala buku tunjangan pedoman guru untuk mengajar dan mempersiapkan kurikulum pembelajaran bagi guru, pengadaan ini dilakukan oleh kepala PAUD sendiri. Mustari (2014:120) pengadaan sarana prasarana sekolah melalui sistem perencanaan dan pengadaan yang hati- hati dan seksama, sehingga sekolah memiliki sarana prasarana sesuai dengan kebutuhan. Sedangkan menurut Arikunto (1993: 82) bahwa pengadaan alat pelajaran tidak semudah pengadaan meja kursi yang hanya mempertimbangkan selera dan dana yang tersedia, untuk proses pengadaan alat pelajaran diperlukan pertimbangan yang lebih banyak, dan semuanya bersifat eduktif.

3. Inventarisasi Sarana dan Prasarana PAUD

Adapun inventarisasi yang dilakukan pada PAUD adalah mencatat dan mendaftar barangbarang milik sekolah kedalam suatu daftar inventaris barang sacara tertib dan teratur. Kegunaan pencatatan barang-barang tersebut yakni untuk diketahui jumlah perlengkapan yang ada dan setiap sarana yang ada diberikan kode supaya tidak mudah hilang. Inventarisasi ini digunakan untuk mencatat segala barang yang diperoleh untuk sekolah sehingga bisa dicatat tertata dengan rapi bentuk barang yang sudah diterima. Inventarisasi yang dilakukan yaitu, seperti mencatat barang-barang serta menyusun daftar barang yang menjadi milik sekolah, tujuannya adalah untuk ketertiban administrasi. Inventarisasi adalah dokumen tempat penyimpan jenis barang yang sudah dimasukan kedalam daftar inventarisasi, baik barang bergerak maupun barang yang tidak bergerak. Inventarisasi 
sekolah ini untuk mempermudah dalam pengontrolan serta pengecekan barang yang sudah pernah diterima serta untuk kerapian barang-barang dalam penyimpanan. Arikunto (1993:86) pencatatan alat kedalam buku daftar inventarisasi. Yang dimaksud dengan buku inventarisasi adalah buku yang dipergunakan untuk mencatat semua kekayaan sekolah.

4. Pemanfaatan Sarana Prasarana PAUD

Pemanfaatan sarana prasarana di PAUD adalah pemanfaatan segala jenis barang yang ada dilingkungan sekolah. Pemanfaatan sarana prasarana PAUD seperti pemanfaat barang yang ada untuk dijadikan bahan ajaran sesuai dengan materi yang disampaikan oleh guru, yang melaksanakannya adalah guru, kepala PAUD hanya menyediakan sarana- prasarana penunjang bagi guru. Pemanfaatan sarana prasarana ini, seperti barang yang bergerak maupun barang yang tidak bergerak seperti didalam ruangan atau diluar ruangan, sudah sesuai dengan perkembangan anak, kenapa dikatakan sudah sesuai dengan perkembagan anak, misalnya alat belajar, alat bermain semua sesuai dengan tujuan yang dicapai, serta kesesuaian antar media yang digunakan sudah sangat baik. Arikunto (1993:87) penggunaan alat pelajaran untuk semua kelas dapat dilakukan dengan membawa alat ke kelas yang membutuhkan secara bergantian atau murid yang akan menggunakan mendatangi ruang khusus. Penggunaan manajemen sarana prasarana, seperti pemanfaat barang yang ada untuk dijadikan bahan ajaran sesuai dengan materi yang disampaikan oleh guru, yang melaksanakannya adalah guru, kepala TK hanya menyediakan sarana-prasarana penunjang bagi guru.

5. Pemeliharaan Sarana Prasarana PAUD

Pemeliharaan sarana dan prasarana dilakukan oleh pengelola PAUD, guru dan siswa, seperti kebersihan sekolah, perawatan cat gedung, pagar, penataan taman serta alat permainan setelah digunakan maka guru mengajak anak-anak untuk bersama-sama menyimpan atau membereskan mainan ketempat semula agar bisa digunakan jangka panjang. Pemeliharaan dilakukan setiap hari melakukan pemeliharaan semua warga sekolah terlibat dalam pemeliharaan barang bergerak maupun barang yang tidak bergerak, namun dalam setiap pemeliharaan ini ada orang-orang yang dikhususkan untuk melakukan pemeliharaan. Berdasarkan pendapat tersebut dapat disimpulan bahwa pemeliharaan adalah kegiatan merawat, memelihara dan menyimpan barang- barang sesuai dengan jenis barangnya, sehingga tetap awet dan tahan lama, dalam melakukan pemeliharaan ini adalah semua warga sekolah terlibat baik terhadap barang bergerak maupun barang yang tidak bergerak, dalam pemeliharaan ini ada juga orang-orang yang dikhususkan untuk melakukannya, sehingga bisa meningkatkan kinrja sekolah terhadap perawatan barang. Mustari (2014:121) perawatan sarana prasarana dapat berjalan dengan baik, sehingga bisa meningkatkan kinerja sekolah, memperpanjang usia pakai, menurunkan biaya perbaikan dan menetapkan biaya efektif perawatan sarana prasarana.

6. Penghapusan atau pemusnahan Sarana Prasarana PAUD

Barang yang sudah tidak layak dipakai bisa di musnahkan tetapi melalui pencatatan terlebih dahulu agar apabila barang tersebut di tanyakan akan memiliki rekam jejak yang jelas 


\section{Simpulan}

Berdasarkan hasil pemaparan studi literature maka kesimpulan pengelolaan sarana dan prasarana pada PAUD adalah bentuk pengelolaan sarana dan prasarananya yaitu merencanakan perlengkapan sekolah sesuai prosedur, mengadakan perlengkapan sekolah, inventarisasi sarana dan prasarana sekolah, memanfaatkan sarana dan prasarana secara kondusif, serta memelihara sarana dan prasarana dengan baik.

\section{Referensi}

Anwar, Moch. Idoch. 2004. Administrasi Pendidikan dan Menajemen Biaya Pendidikan. Bandung: CV Alpabeta. Arikunto, Suharsimi. 1993. Organisasi dan Administrasi Pendidikan Teknologi dan Kejuruan. Yogyakarta: Grafindo Persada.

Burhanuddin. 1994. Analisis Administrasi Menejemen dan Kepemimpinan pendidikan. Jakarta: Bumi Aksara.

Buhanuddin, Yusak. 1990. Administrasi Pendidikan. Bandung: CV Pustaka setia.

Bafadal, Ibrahi. 2003. Menejemen Perlengkapan Sekolah dan Aplikasinya. Jakarta: Bumi Aksara.

Cardoso, Fausitisno. 2001. Menejemen Sumber Daya Manusia dan Kepemimpinan Pendidikan. Jakarta: Bumi Aksara.

Daryanto, M. 2005. Administrasi Pendidikan. Jakarta: Rineka Cipta.

Depdikbud. 1996. Kamus Besar Bahasa Indonesa. Jakarta: Balai Pustaka. Douglas,

Hart R. 1963. Modern Administration of Secondary. Boston: Ginn \& Company.

Mulyasa, E,. 2002. Menejemen Berbasis Sekolah Konsep, Strategi, dan Implementasi. Bandung: PT Remaja Rosdakarya.

Peter dan Salim Yeni. 1991. Campus bahasa Indonesa Komteporer. Jakarta: Modern English Press.

Pidarta, Made. 2004. Manajemen Pendidikan Indonesia. Jakarta: PT. Rineka Cipta.

Purwanto Ngalim. 1987. Administrasi dan Supervisi Pendidikan. Bandung: PT Remaja Rosdakarya.

Soerjan. 1988. Sarana dan Prasarana. Jaklarta: Bumi Aksara

Sugiono. 2007. Metode penelitian kualitatif kuantitatif dan $R \& D$. Bandung: Alfabeta.

Tahalele, J.F\& dan Soekarno Indrafacrudi. 1975. Kepemimpinan pendidikan. Malang: Sub Proyek Buku Pelajaran P3T, IKIP Malang.

Wahyuningrum. 2000. Buku Ajar Menejemen Fasilitas Pendidikan. Yogyakarta: FIP. Mohamad, Mustari. (2015). Manajemen Pendidikan. Jakarta: PT RajaGrafindo Persada. Minarti, Sri. (2016). Manajemen Sekolah. Jogjakarta: AR- RUZZ MEDIA. Suparlan. (2013). Manajemen Berbasis Sekolah. Jakarta: PT Bumi Aksara.

Arikunto, Suharsimi. (1993). Organisasi Dan Administrasi. Jakarta: PT RajaGrafindo Persada. 